\title{
COMPARISON OF SITUATIONAL LEADERSHIP IN THE MANAGEMENT OF FOREST
}

\author{
Ginung Pratidina
}

State Administration Study Program Djuanda University, Bogor-16720, Negara, Indonesia.

\section{Berry Sastrawan}

State Administration Study Program Djuanda University, Bogor-16720, Negara, Indonesia.

\section{Abubakar Iskandar}

State Administration Study Program Djuanda University, Bogor-16720, Negara, Indonesia.

\begin{abstract}
Minister of LHK Decree No. 327/Menlhk/Setjen/PLA.2/4/2016 Concerning Changes in Functions of Some Forest Areas of the Mount Halimun-Salak National Park (MHSNP), which was initially 113,357 hectares wide, now only 87,699 hectares. Around that area, 100,000 people depend on their livelihoods on land in the MHSNP forest area. Therefore, the purpose of this study is to compare formal and informal leadership with the perspective of situational leadership in forest management with descriptive qualitative research methods. The research sample informal leadership is MHSNP using the technique Disproportionate Stratified Random Sampling, and the results obtained are 32 respondents, and for informal leadership, Kasepuhan uses the technique Cluster Sampling with a sample size of 120 respondents. Data collection techniques through observation, questionnaires, interviews, and literature studies. Then the data is analyzed with descriptive data analysis techniques. The results showed that both the Head of the MHSNP Office and the Indigenous Head applied situational leadership dominated by a style of consultation with a value of 2.10 (MHSNP) and 2.66 (Kasepuhan), where the head of the hall and the customary head in leading showed a lot of directing behavior and many gave support, want to consult decisions and policies taken and want to receive opinions from employees, but must continue to oversee employees in completing the tasks of employees, in making decisions remain on the leader and communication is done both ways between the leader and subordinates. However, the leadership of the Customary Head has gradually entered the Situational Leadership with Participatory Style.
\end{abstract}

Key words: consultation style, participation, indigenous peoples, sustainable forest Management

Cite this Article: Ginung Pratidina, Berry Sastrawan and Abubakar Iskandar, Comparison of Situational Leadership in the Management of Forest, International Journal of Management, 10 (6), 2019, pp. 338-345.

http://iaeme.com/Home/issue/IJM?Volume $=10 \& I s s u e=6$ 


\section{INTRODUCTION}

\subsection{Background}

Every year the forest area in Indonesia is always experiencing deforestation, the fact shows from the Ministry of Environment and Forestry of the Republic of Indonesia, that the decline in forest area in the period of 2014 to 2015 reached 1.09 million hectares, and in the period of 2015 to 2016 it became 0.63 million hectares and in 2017 the forest area is now 125,922,474 hectares (Hedi Novianto, 2018) [1]. Whereas in 2019, based on data from the Directorate of Forest and Land Fire Control, Indonesia experienced Land and Forest Fires in 32 Provinces covering 328,722 hectares(Manggala Agni, 2019) [2]. One area that has experienced a change in forestry function is the Mount Halimun-Salak National Park in 2016, which has decreased Conservation Forest Area due to land conversion, the initial area of conservation of the Mount Halimun-Salak National Park in 2003 based on Forestry Minister's Decree Number 175 covering 113,357 hectares (Ministry of Forestry, 2003) [4], in 2016 based on Decree of the Ministry of Environment and Forestry Number 327/Menlhk/Setjen/PLA.2/4/2016 concerning Changes in Functions of Some Forest Areas of the Mount Halimun-Salak National Park (MHSNP), which covers an area of 87,699 hectare (Ministry of Environment and Forestry, 2016) [3]

There are more than 100,000 people who depend on their livelihoods on land in the forests of Mount Halimun-Salak National Park (Supriyanto, B \& Ekariyono, 2007) [8]. Therefore, in the forest area, there are two interests, namely the community and the Government, on the one hand, the community needs natural resources for their livelihoods which are sometimes excessive in utilizing them, on the other hand, the government has a conservation interest which is maintaining the forest for sustainability. Therefore, it is not uncommon for conflict between the community and the government, what is unique in the forest area of the Mount HalimunSalak National Park is the existence of indigenous peoples, who also live adjacent to conservation forests, despite the fact that indigenous peoples first existed in protecting forest before the arrival of the Halimun-Salak Mountain National Park. Because the government has formal legal force, the forests claimed by indigenous peoples cannot be recognized by them, because formal legal power is in the state. The problem is not simply because the Mount Halimun-Salak National Park area is unique, where, in some areas, there are two systems of government, namely formal governance headed by the Village Head, and non-formal governance headed by the indigenous chief of Kasepuhan. The role of the leader in government is significant, considering the leader's function as an agent of change to carry out government programs that involve the participation of the community.

Both forms of leadership support each other in the social life of the community. However, in the effort to manage forests, indigenous people are very obedient to their customary leaders, in the sense of what words are prohibited by their traditional leaders, the people do not dare to violate them. This heterogeneity gives rise to several groups of people whose sense of regional culture is strong because the difference is seen from the habits and procedures of the community. One community that has two informal and formal leadership in one area is Sirnaresmi Village, Cisolok Subdistrict, Sukabumi Regency. In that village, there are three traditional community leaders commonly called Kasepuhan, namely Kasepuhan Cipta Mulya, Sirna Resmi, and Ciptagelar. These three Kasepuhan are in the administrative area of the village of Sinar, officially led by the formal leadership of the village head. Also, the official Sinar Village is within the Conservation Forest Area, namely the Halimun-Salak Mountain National Park. When there is a program from the government, both leadership (formal and informal) communicate and coordinate with each other, it's just that sometimes there is a dualism of interests, one example in forest governance, where indigenous peoples have traditions, views, 
access to forests for life, while good government The village government and Gunung HalimunSalak National Park also have an interest in forest conservation. This often causes a conflict of interest. So that every problem the role of the leader is significant in dealing with situations and conditions that occur.

\subsection{Research Purposes}

The objectives of this study are as follows:

1. To find the influence of Situational Leadership on Management of Forest

2. Comparison of Situational Leadership between Indigenous Peoples and the Mount Halimun-Salak National Park Office

3. Comparison of Forest Management between Mount Halimun-Salak National Park and Indigenous Peoples

\section{DATA USED AND SITUATIONAL LEADERSHIP}

\subsection{State of the Art}

The results of research from (Sastrawan, 2015) [7], conclude that in solving problems when there are conflicts between indigenous and non-indigenous communities with the HalimunSalak Mountain National Park, it has the possibility of responding to a compromising conflict management style response because it is based on research results by distributing questionnaires, each has scores in a structured 9,10 and 10 with each percentage of possible response choices in conflict situations or conditions between $80 \%-90 \%$, and local communities (indigenous and non-indigenous) above $90 \%$ which are in high quadrant in choosing solutions through compromise (Sastrawan, 2015) [7]. This proves the existence of a common mind and good intentions of the Government, in this case, the Mount Halimun-Salak National Park and the community, only that this form of intense communication between stakeholders has not been developed intensively and openly with each other.

According to (Rahmawati, 2013) [6], in conservation forests, conflicts usually involve the government, non-governmental organizations (NGOs) and local communities (indigenous and non-indigenous). Conflicts occur because of differences in interests in the forest. In conservation forests, the government has an interest in conserving forests because in Law number 41 of 1999 article 6 that forests have three functions, namely conservation, protection, and production functions. Whereas NGOs have two functions, namely to control the State and at the same time, strengthen the capacity of indigenous and local communities in realizing good governance. Whereas indigenous or local communities, forests function as a source of community life. This difference of opinion is what caused the conflict (Rahmawati, 2013) [6].

While (Pratidina's research results, 2012) [5[, stated that one of the Mount Halimun-Salak National Park Program is to offer the Conservation Village Model (CVM) program in collaboration with the Japan International Cooperation Agency with the establishment of 37 CVM but after the death of Japan International Cooperation Agency, the remaining only 5 CVM only. 5 This MKK turned out to be only effective for non-Indigenous people, one of which was in Kampung Sukagalih, Cipeuteuy Village, Sukabumi District (Pratidina, 2012) [5]. The CVM program is not effective in indigenous communities because of the dual leadership in an indigenous community, even though indigenous communities have a system in managing their forests.

\section{METHODS}

The results of the above study show that each case has a key that is dependent on the decision of the leader of each institution. Therefore, this study wants to examine and develop previous 
research on situational leadership in formal and informal institutions with descriptive qualitative research methods, with samples taken from the Mount Halimun-Salak National Park Office employees using Disproportionate Stratified Random Sampling totaling 32 employees. The sampling technique used for the population in this study uses several stages, first with the technique Cluster Sampling, so that it is divided into three indigenous communities. Next is the technique of Non-probability Sampling. One of the techniques Non-Probability sampling that are considered suitable for this study is the Technique Purposive Sampling so that a sample of 120 respondents is obtained.

\section{RESULTS AND DISCUSSION}

\subsection{Results and discussion at the Center for Situational Leadership MHSNP}

Table 1 Summary of results for each dimension of the Situational Leadership in the Mount HalimunSalak National Park

\begin{tabular}{|c|c|c|c|c|}
\hline Dimension & Values & $\begin{array}{l}\text { Leadership } \\
\text { Style }\end{array}$ & Description & Example \\
\hline Instruction & 1.38 & Instruction & $\begin{array}{l}\text { Demonstrate behaviors that } \\
\text { are giving direction (in the } \\
\text { task behavior) and a little } \\
\text { support (in relationship } \\
\text { behavior). Give instructions } \\
\text { specific about the role and } \\
\text { objectives of his followers }\end{array}$ & $\begin{array}{l}\text { Orders to carry out } \\
\text { directives from the } \\
\text { General Director of } \\
\text { KSDAE Consultation }\end{array}$ \\
\hline Supervision & 1.53 & Instructions- & Strict Enough Monitoring & $\begin{array}{l}\text { View monthly } \\
\text { performance and } \\
\text { financial reports to be } \\
\text { used as a future } \\
\text { evaluation }\end{array}$ \\
\hline Communication & 3.16 & Participation & $\begin{array}{l}\text { Two-way communication } \\
\text { and the role of leaders } \\
\text { actively listening }\end{array}$ & $\begin{array}{l}\text { In Meeting to solve } \\
\text { problems both internal } \\
\text { and external }\end{array}$ \\
\hline $\begin{array}{l}\text { Problem- } \\
\text { solving } \\
\text { initiative }\end{array}$ & 2.47 & Consultation & $\begin{array}{l}\text { Problem-solving initiatives } \\
\text { still exist with the } \\
\text { leadership, but some } \\
\text { technical initiatives from } \\
\text { employees }\end{array}$ & $\begin{array}{l}\text { The problem of land } \\
\text { conflicts between } \\
\text { communities and Centers }\end{array}$ \\
\hline $\begin{array}{l}\text { Decision- } \\
\text { Making }\end{array}$ & 1.88 & $\begin{array}{l}\text { Instructions- } \\
\text { Consultation }\end{array}$ & $\begin{array}{l}\text { on decision-making } \\
\text { remains on leaders, but } \\
\text { certain cases begin to } \\
\text { involve subordinates }\end{array}$ & $\begin{array}{c}\text { Meeting Decisions } \\
\text { produced by the majority } \\
\text { of the Leaders }\end{array}$ \\
\hline $\begin{array}{c}\text { Role of } \\
\text { Employees }\end{array}$ & 2.22 & Consultation & $\begin{array}{l}\text { Limiting the role/duties of } \\
\text { employees based on the } \\
\text { main tasks and functions, } \\
\text { but in the implementation } \\
\text { began to be given freedom. }\end{array}$ & Staffing and ASN Rules \\
\hline
\end{tabular}

Source: Research Results, 2019

From table 1 above, it can be concluded that the situational leadership style used by the Office head according to the existing dimensions is the consultation style because the intensity of the use of this style is more frequent than other styles with a value of 210 . Therefore the description based on the existing dimensions, situational leadership at the Mount Halimun- 
Salak National Park Office, is a consultation style that has a definition that is a leader who shows a lot of direction (in task behavior) and little support (in relationship behavior) - thus giving specific instructions about the role and objectives of his followers with quite strict supervision. Two-way communication and the part of leaders actively listening. But in the problem-solving initiative there is still the leadership, but some technical initiatives from the employee so that the decision making remains with the leader, but certain cases begin to involve subordinates and limit the roles/tasks of employees based on the main tasks and functions, but in the implementation began to be given freedom.

\subsection{Results and Discussion of Situational Leadership in Indigenous Peoples}

Table 2 Recapitulation of each Dimension in Situational Leadership in Indigenous Peoples

\begin{tabular}{|c|c|c|c|c|}
\hline Dimensions & Values & $\begin{array}{l}\text { Leadership } \\
\text { Style }\end{array}$ & Description of & Case \\
\hline Instructions & 2.70 & $\begin{array}{l}\text { Consultation- } \\
\text { Participation }\end{array}$ & $\begin{array}{l}\text { Shows behavior that is } \\
\text { highly directing, but in } \\
\text { providing support } \\
\text { sometimes a lot depends } \\
\text { a little on conditions } \\
\text { and the situation of } \\
\text { subordinates }\end{array}$ & $\begin{array}{l}\text { of the Indigenous Head } \\
\text { getting a new program } \\
\text { from the government, the } \\
\text { Indigenous Head needs to } \\
\text { explain and provide many } \\
\text { directions so that it can be } \\
\text { carried out correctly. }\end{array}$ \\
\hline Oversight & 2.48 & Consultation & $\begin{array}{l}\text { Leaders must continue } \\
\text { to provide supervision } \\
\text { in completing the tasks } \\
\text { of followers or } \\
\text { subordinates } \\
\end{array}$ & $\begin{array}{c}\text { Oversee the } \\
\text { implementation of } \\
\text { Indigenous peoples' paddy } \\
\text { rice harvest }\end{array}$ \\
\hline Communication & 2.82 & $\begin{array}{l}\text { Consultation- } \\
\text { Participation }\end{array}$ & $\begin{array}{l}\text { Has conducted two-way } \\
\text { communication between } \\
\text { leaders and assistants } \\
\text { and certain conditions } \\
\text { two-way } \\
\text { communication } \\
\text { improved and certain } \\
\text { conditions more } \\
\text { actively listened to }\end{array}$ & $\begin{array}{l}\text { deliberations and plans to } \\
\text { implement Seren Taun two } \\
\text { communication occurred, } \\
\text { and when guests came to } \\
\text { the customary head, the } \\
\text { customary head was more } \\
\text { active listening to }\end{array}$ \\
\hline $\begin{array}{l}\text { the problem- } \\
\text { solving } \\
\text { initiative }\end{array}$ & 3.22 & Participation & $\begin{array}{l}\text { position of control over } \\
\text { problem-solving and } \\
\text { decision making was } \\
\text { held alternately between } \\
\text { the leader and } \\
\text { subordinate }\end{array}$ & $\begin{array}{l}\text { When the problem is } \\
\text { related to } \text { Sara or religion, } \\
\text { it is resolved by Ustadz, } \\
\text { but sometimes it is also } \\
\text { determined customarily by } \\
\text { the customary head. }\end{array}$ \\
\hline $\begin{array}{l}\text { Decision } \\
\text { Making }\end{array}$ & 1.88 & $\begin{array}{l}\text { Instructions- } \\
\text { Consultation }\end{array}$ & $\begin{array}{l}\text { on decision-making } \\
\text { solely carried out by the } \\
\text { leader }\end{array}$ & $\begin{array}{l}\text { Deliberation continues to } \\
\text { be carried out, but in the } \\
\text { end, the final decision is } \\
\text { submitted in the Head of } \\
\text { Customary }\end{array}$ \\
\hline $\begin{array}{l}\text { Community } \\
\text { Role }\end{array}$ & 2.88 & $\begin{array}{l}\text { Consultation- } \\
\text { Participation }\end{array}$ & $\begin{array}{l}\text { Has a limited role } \\
\text { following its main task } \\
\text { but in implementation } \\
\text { given freedom of origin } \\
\text { breaking the rules } \\
\text { because the subordinate }\end{array}$ & $\begin{array}{l}\text { Taking wood in the } \\
\text { customary forest to make a } \\
\text { house, the customary head } \\
\text { allowed with the necessary } \\
\text { limits and gave conditions } \\
\text { to replant tree seedlings }\end{array}$ \\
\hline
\end{tabular}




\begin{tabular}{|l|l|l|c|}
\hline & & $\begin{array}{c}\text { has a good ability to } \\
\text { carry out the task of }\end{array}$ & $\begin{array}{c}\text { and guarded and did not } \\
\text { sell the wood. }\end{array}$ \\
\hline
\end{tabular}

Source: Research Results, 2019

From table 2 above, it can be concluded that the situational leadership style used by customary leaders according to the existing dimensions is a mixture of consultation style and participation style, although more often the consultation style is also almost balanced with the participation style with a value of 2.66. Therefore the description based on the existing dimensions, situational leadership in indigenous peoples is participatory consultation that has a definition of a leader with a mixed style of consultation and participation showing a lot of directing behavior, but in giving support sometimes a lot a little. The leader must continue to provide oversight in completing the tasks of followers or subordinates, but not too strict. Communication is carried out in both directions, but certain conditions are improved, and certain conditions are more active in listening. The position of control over problem-solving and decision making is held alternately between leaders and subordinates. But the final decision remains with the leadership. Then within the limits of the role following the main tasks, but in the implementation given freedom because subordinates can carry out their duties properly.

\subsection{Comparison of Situational Leadership between Indigenous Peoples and the Mount Halimun-Salak National Park Office}

Table 3 Comparison of Situational Leadership between the Indigenous Peoples and the Mount Halimun-Salak National Park Hall

\begin{tabular}{|c|c|c|c|c|c|c|c|}
\hline $\mathrm{A}$ & $\mathrm{B}$ & $\mathrm{C}$ & $\mathrm{D}$ & $\mathrm{E}$ & $\mathrm{F}$ & $\mathrm{G}$ & $\mathrm{H}$ \\
\hline $\begin{array}{c}\text { Indigenous } \\
\text { Peoples }\end{array}$ & 2.70 & 2.48 & 2.82 & 3,22 & 1.88 & 2.88 & 2.66 \\
\hline Office MHSNP & 1.38 & 1.53 & 3.16 & 2.47 & 1.88 & 2.22 & 2.10 \\
\hline
\end{tabular}

Source: Research Results, 2019

\section{Description:}

\begin{tabular}{|l|}
\hline A: Comparison Object \\
B: Instructions \\
C: Oversight \\
D: Communication \\
E: Decision Making Initiative \\
F: Decision Making \\
G: Role \\
H: Average \\
\hline
\end{tabular}

From the table above shows that the average of all situational leadership in formal and informal leadership tends to be the style of consultation where this style has a lot of behavior to give directing and providing much support in making decisions willing to accept opinions from followers and communication is done in two directions. However, there are different Indigenous people, that is, indigenous peoples have a value of 2.66 , which means that they begin to enter into a style of participation where decisions are always made in consultation, and the customary head always explains why making these decisions, because indigenous institutions are informal institutions that are not rigid, rigid and not bound by hierarchical. 


\subsection{Comparison of Forest Management between Mount Halimun-Salak National Park and Indigenous Peoples}

Table 4 Forest Governance Map

\begin{tabular}{|c|c|c|c|}
\hline & $\begin{array}{l}\text { Core Zone / Forest Cover / } \\
\text { Government-Owned Forest }\end{array}$ & $\begin{array}{c}\text { Jungle Zone / Secured } \\
\text { Forest / Government- } \\
\text { Owned Forest }\end{array}$ & $\begin{array}{l}\text { Rehabilitation Zone / } \\
\text { Open Forest / }\end{array}$ \\
\hline $\begin{array}{c}\text { Cultivation of } \\
\text { Mount Halimun } \\
\text { National Park- } \\
\text { Salak }\end{array}$ & $\begin{array}{l}\text { It is a part of a national park } \\
\text { that has natural conditions } \\
\text { both biotic and physical are } \\
\text { still original and not or have } \\
\text { not been disturbed by } \\
\text { humans, which are protected, } \\
\text { functions to protect the } \\
\text { representation of the original } \\
\text { and unique biodiversity. }\end{array}$ & $\begin{array}{l}\text { The inside of a national } \\
\text { park which because of its } \\
\text { location, condition and } \\
\text { potential can support } \\
\text { conservation interests in } \\
\text { the core and utilization } \\
\text { zones. }\end{array}$ & $\begin{array}{l}\text { Part of the national park } \\
\text { that is damaged, so it is } \\
\text { necessary to carry out } \\
\text { activities to restore the } \\
\text { damaged biological } \\
\text { community and its } \\
\text { ecosystem. }\end{array}$ \\
\hline $\begin{array}{l}\text { Indigenous } \\
\text { People This }\end{array}$ & $\begin{array}{l}\text { Is the forest entrusted by the } \\
\text { ancestors that should not be } \\
\text { entered by just anyone? As } \\
\text { Leuweung Sirah Cai (storage } \\
\text { of water reserves). And as a } \\
\text { spiritual place for the people. }\end{array}$ & $\begin{array}{l}\text { It is a forest that is } \\
\text { allocated for future } \\
\text { settlement (Awisan) and } \\
\text { later arable land. Forest } \\
\text { cover may only be entered } \\
\text { with the permission of the } \\
\text { Head of Customary Affairs } \\
\text { to extract timber and non- } \\
\text { timber forest products. }\end{array}$ & $\begin{array}{l}\text { The forest has been } \\
\text { cleared for arable land to } \\
\text { meet the food and wood } \\
\text { (wood) needs of the } \\
\text { community. }\end{array}$ \\
\hline $\begin{array}{l}\text { Non-Indigenous } \\
\text { Community } \\
\text { This }\end{array}$ & $\begin{array}{l}\text { Is a protected forest that is } \\
\text { fully managed by the } \\
\text { government, so it is forbidden } \\
\text { to take anything in it and, as a } \\
\text { community, can only obey } \\
\text { government regulations }\end{array}$ & $\begin{array}{l}\text { It is a forest that must be } \\
\text { protected, preserved, and } \\
\text { maintained intact by the } \\
\text { government for the benefit } \\
\text { of the surrounding } \\
\text { community. }\end{array}$ & $\begin{array}{l}\text { It is an area of agricultural } \\
\text { agriculture that has a } \\
\text { significant role in the } \\
\text { community's primary } \\
\text { needs. }\end{array}$ \\
\hline
\end{tabular}

Source: Research Results, 2019

The view of the core zone between the government and local communities has the same opinion, that is, forest cover and core zone do have to be protected together. While the Titipan Forest / Jungle Zone has a different perspective, that is, the Halimun-Salak National Park is still a protected forest with a second layer, but according to the Indigenous people, the timber may be taken as long as it is not sold and only used for buildings, and to enter the forest, a permit must be obtained from the customary head (Abah) and according to non-indigenous people, the function of the jungle zone is the same as the core zone, only there are some unscrupulous people who take wood and other benefits clandestinely from this zone. However, indigenous peoples have lost access to these entrusted forests, especially when there has been an expansion of the national park until now.

The rehabilitation zone, according to the National Park is a zone that needs to be improved so that it becomes a dense forest again, while according to indigenous and non-Indigenous communities, this land is a community arable land for meeting primary needs. So that in this zone, there are many potential conflicts between the Mount Halimun-Salak National Park and the local community because on one side of the National Park aims to preserve the forest, on the other hand, the community needs cultivation and can only become farmers for their primary needs.

\section{CONCLUSION}

Based on the results and discussion, the conclusion of this study is that situational leadership both on the leadership of customary leaders and on the leadership of the head of the hall, both 
have similarities in leading the institution namely situational leadership with consultation style, but in communication has a slight difference that is in the indigenous chief's leadership in communication is more on a participatory style where the indigenous head carries out two-way communication and tends to listen more, and participate in carrying out activities in his customary community, because the leadership adopted is a model leader whereas the leadership of the head of the communication center is only two directions.

Whereas comparisons in the management of national park forests with indigenous peoples have similarities in the function of forest management, namely forests Tutupan with core zones, forests Titipan with Jungle zones, and forests Open with Rehabilitation Zones. But within territorial boundaries where the forest area Garapan according to the Indigenous people with the core zone according to the Mount Halimun-Salak National Park, is different, including other zones. This is one of the causes of conflicts of interest over forest access that has not been resolved until now. Whereas the Non-Indigenous people, in this case, there is no regulation from them to protect the forest, the Non-Indigenous people give more forest management entirely to the government and are ready to participate if the government needs help from the community in terms of preserving the forest.

\section{REFERENCES}

[1] Hedi Novianto, Indonesia's Forest Area is shrinking. Retrieved from Beritagar website: https://beritagar.id/artikel/berita/luas-hutan-indonesia-menyusut, 2018

[2] Manggala Agni, Recapitulation of Forest and Land Fire Area (Ha) Per Province in Indonesia in 2014-2019. Retrieved from PKHL Directorate of the Ministry of Environment and

ForestryoftheRepublicofIndonesiawebsite:http://sipongi.menlhk.go.id/hotspot/luas_kebak aran, 2019

[3] Ministry of Environment and Forestry. Changes in Functions of Some Forest Areas of Mount Halimun-Salak National Park. , Pub. L. No. 314/MENLHK/SETJEN/PLA.2/4/2016 (2016).

[4] Dr. Antony Joe Raja. V., A Study on Resource Management, Economic Approach, Leadership Quality In Variouse Organisation In The World. International Journal of Management, 6(7), 2015, pp. 37-46.

[5] Ministry of Forestry. Appointment of Mount Halimun National Park Area and Change in Function of Protected Forest Areas, Permanent Production Forests, Limited Production Forests in the Mount Halimun Forest Group and Mount Salak Forest Area of $\pm 113,357$ hectares. , Pub. L. No. 175/Kpts-II/2003 (2003).

[6] Pratidina, G, Optimizing the Implementation of the Conservation Village Model Policy in Community Empowerment around the Mount Halimun-Salak National Park. Bogor, 2012

[7] Pradip Kumar Krishnadevarajan, S. Balasubramanian, N. Kannan and Vignesh Ravichandran. A Multi-Criteria Decision Framework for Inventory Management. International Journal of Management, 7(1), 2016, pp. 85-93.

[8] Rahmawati, R, Forest Resource Conflicts in West Java and West Kalimantan. Bogor, 2013

[9] Sastrawan, B, Conflict Management in the Forest Management of Mount Halimun-Salak National Park. Bogor, 2015

[10] Mr. Mohammed Rafeeq, Ms. Asma .S, Mr. Zameer Ahmed, Mr. Palparthi Rajesh, Business Ethics, Corporate Culture and Strategic Leadership for Organizational Effectiveness, International Journal of Advanced Research in Management (IJARM), Volume 5, Issue 5, September-October (2014), pp. 01-09

[11] Supriyanto, B \& Ekariyono, W, Five reconstruction and social conservation strategies in the Halimun-Salak National Park. Sukabumi, 2007 